\title{
Intertextuality Study on the Meaning of a Woman's Body in the Relief Panels of Borobudur Temple
}

\author{
Des Hanafi \\ Students Ph.D. Program of Science Communication \\ Post Graduate School of Sahid University \\ Jakarta, Indonesia \\ Mirza Ronda \\ Lecture \\ Post Graduate School of Sahid University \\ Jakarta Indonesia \\ Mikhael Dua \\ Lecture \\ Post Graduate School of Sahid University \\ Jakarta Indonesia
}

\begin{abstract}
One of the interesting things to observe when visiting Borobudur temple is the relief panels on the walls of the temple. Relief panels at Borobudur Tempe tell many stories in the display of mostly topless female bodies. Various meanings and messages shall reveal when one observes the relief panels of Borobudur Temple closely, which was built before 800 AD. These meanings can be studied both practically and academically. Different looks of female figures is displayed in accordance with their roles. The symbols and signs of the female body on the relief panels of Borobudur Temple can be treated as texts conveying a message about the lives of women in that era. Qualitative research method and interpretive paradigm are used in accordance with branches of semiotics, including genotext, fenotex, and intertextual studies, as the main basis when reading or interpreting the relief panels displaying female bodies at Borobudur Temple.
\end{abstract}

Keywords: relief panels, body, feminist, qualitative, intertextual

\section{Introduction}

The beauty and magnificence of a woman's body has never been just a myth or mere texts in works of art and literature. Women assume that beauty is a nature of themselves. For some of them, life goals may include having a nice and beautiful body. They may feel proud of their fair skin, tall and slim figure, and other beauty elements attached to a woman's body. This pride in beauty is not only enjoyed by women themselves, but also by men. The pride of men is expressed in different ways, starting from the desire to have beautiful women, just enjoying the view of women's bodies with or without fantasizing them, to enjoying them in the form of paintings or sculptures and other works of art.

A display of a woman's bodies in the relief panels, in addition to telling stories about the natural conditions in the era, comes with different moral messages, including showing how a mother cares for and educates her children, and showing a woman's loyalty to her partner or vice versa. The walls of the temple become an art stage displaying the female body perfectly in public spaces.

In conducting a text research on a woman's body, the current researchers firstly take a look at the definition of a female body, including the existence and the problems of it. The researchers suggest that it must be understood as something more than just a human frame. The body is a physical condition of a person which can function outwardly and spiritually (verbal - non verbal). Thus, sexuality cannot be separated from the discussion of roles of the body as an object.

Despite the fact that it is taboo to frequently talk about a human's body and the sexuality, especially a woman's, they have always been discussed since the ancient times. A woman's body is a part of socially shaped eroticism (Arsam, 2016: 1). As an object and a symbol of sexuality, a portrayal of a woman's body can be found in products of arts and cultures, including paintings, statues and sculptures on temples, accompanying a variety of texts interpreted from myths or urban legends. 
The problems of the female body existence are contained in the texts contained in works of art, including sculptures. According to the researcher, an existence is related to how humans view each other based on personal experiences, to give rise to both social and cultural meanings. The thoughts on the meaning of a woman's body will continue along with the increasing frequency of talks or discussions about women and their basic problems, including the body and the sexuality.

For example, when a man sees a woman, the first thing he will be focused on is the vital area of the woman's body, fantasizing about it. It is very unusual for men to think about the nature or the character or the behavior of the woman right at the moment he sees her. Sheldon states that people can be classified into three body types, including endomorphic (fat, soft), mesomorphic (athletic) and ectomorphic (thin). Wells then elaborate on it by mentioning that people with an endomorph body tend to look old-fashioned, lazy, fussy, sympathetic, warm, easy to agree, more dependent on others, and more trusting to others (Sihabudin, 2013: 100).

Meanwhile, people with a mesomorph body are strong, adventurous, more mature, and confident. Furthermore, people with an ectomorph body are more ambitious, suspicious, easily nervous, pessimistic and quiet. The physical attractiveness of one's body more or less affect their social interaction. Those who have a strong body attraction will be more confident in interacting than those who have a low physical attraction.

The body can be seen as a whole from head to toe, or from just a few parts of it. When talking about the body, more attention will be directed at imaging the physically prominent, young, attractive, healthy and sexy figure. However, despite the fact that the conversation about the body, especially the female one, has been going on for centuries, most of the talk still revolves around sex and sexuality.

The shape of a human body will influence the behavior (Sihabudin, 2011: 99). Although many reject the notion that human behaviors can be analyzed based on their body shape, Sihabudin puts forward the opinion of Kretschmer (1970), stating that humans have morphological similarities that can be divided into 3 (three) groups, including asthenic groups (narrow body shape, thin, bone-showing), athletic (muscular body) and pyknic (fat body). Sihabudin emphasizes that in general, a person's physical attractiveness is very important for their everyday interaction. People who have a strong physical attraction will feel successful in interpersonal relationships than those who have a low physical attraction.

Therefore, it is natural for women to want to keep their body beautiful as the beauty of the female body is not just a myth. However, some women assume that beauty is a nature of themselves. For some of them, life goals may include having a nice and beautiful body. They may feel proud of their fair skin, tall and slim figure, and other beauty elements attached to a woman's body. This pride in beauty is not only enjoyed by women themselves, but also by men. It is not uncommon for women to take care of their body with a negative intention, which is to attract men to enjoy their body for an agreed price.

\section{Literature Review}

The discussion on the female body in the realm of social science will never expire. It will be even more developed following the wishes of women; as long as women continue to beautify themselves through so many different ways, the discussion of the female body carries on. Jean Baudrillard (1990: 7-9) mentions that a woman's body is full of seduction.

Baudrillard argues that human body functions on intelligence (and not on desire). With semiotic signs on the body, it may be seduced, tempted, separated from the truth in a moment of passion. This suggests that when separated from religious norms, seduction on the body may result in sometimes cunning and evil actions which are against religious rules.

Piliang in his book, Post-reality, states that the body is produced as a series of texts, a collection of signs combined through certain semiotic codes that produce various meanings or effects of differences needed, for example in capitalism. This suggests that the body is divided into elements of signs such as eyes, lips, nose, cheeks, hair, breasts, hips, calves and others, which is the initial stage of meaning formation. It will finally form a signifier that produces unconventional meanings in the sense that it may be ambiguous, controversial, paradoxical and even ironic (Piliang, 2004: 390).

Studying signs in human body (semiotics) is a way for people to read them as a text linked to life and social communication. However, these signs can sometimes have opposing characters. According to Raditya (2014: xxviii), the body can build a power by transforming it from "over the body" to "from the body". Additionally, the body can be trapped in the reproduction scheme that is often filled with inequality by maintaining certain frames of the body. The beauty and magnificence of a woman's body has never been just a myth or mere texts in works of art and literature. Women assume that beauty is a nature of themselves. For some of them, life goals may include having a nice and beautiful body. 
They may feel proud of their fair skin, tall and slim figure, and other beauty elements attached to a woman's body. This pride in beauty is not only enjoyed by women themselves, but also by men. The pride of men is expressed in different ways, starting from the desire to have beautiful women, just enjoying the view of women's bodies with or without fantasizing them, to enjoying them in the form of paintings or sculptures and other works of art.

In conducting a text research on a woman's body, firstly taking a look at the definition of a female body is necessary, including the existence and the problems of it. The researchers suggest that it must be understood as something more than just a human frame. The body is a physical condition of a person which can function outwardly and spiritually (verbal - non verbal). Thus, sexuality cannot be separated from the discussion of roles of the body as an object.

Semiotization of the body is a mechanism in a social relationship that places the body as a set of signs to be used in communication. However, on the contrary, the signs of the body can be sometimes contradictory, affected by social force and the condition of being the target of exploitation. On the one hand, the body can build a power by transforming it from "over the body" to "from the body". On another, the body can be caught up in the reproduction scheme that is often filled with inequality (Raditya, 2014: xxviii).

In this dissertation study, the researchers use semanalysis, which is Julia Kristeva's semiotic analysis. Semanalysis is a form of final semiological analysis which rejects ideology-free denotation ideas and focuses on how texts create meanings that are contrary to the actual meaning of the text. Semanalysis or semiotic analysis is the desire to see language. Language in sounds or terms can appear the same everywhere, but the use by humans in their respective contexts may give birth to different meanings or new meanings or new significance, and this is what semanalysis is for.

Kristeva's semanalysis states that reading a text can begin with language observation. The marking of an object begins unconsciously, which is then processed in conversations in symbolic groups by analyzing the languages used.

Kristeva mentions that one of the problems in semiotics is to firstly replace, rhetorically, the typology of a text; that is, to determine the specificity of different textual arrangements by placing them in the general text (culture) where they are part of, and which in turn, will be part of them. Ideology is the intersection of textual arrangements given (a semiotic exercise) with utterances (sequences) that can be assimilated into an independent space or that refers to an external text space (semiotic practice).

The terms genotext and phenotext are originated in semanalysis. Genotext is the original text or original meaning (previous meaning), while phenotext is the actual text or meaning understood in the current time. Genotext and phenotext are always present together. According to Kristeva, human daily activities are activities of discourse formation and meanings. The process is called signifier and signified. Semanalysis proposes text theory as a producer of meaning, which is related to how text creates meaning that is contrary to what is originnaly interpreted from it. Therefore, semanalysis has a different perspective on ideology. While linguistic structuralism and early semiology have undermined ideology into language, semanalysis finds ideology in the production of textual meaning.

Creation of meaning is a form of intertextuality (ie the text does not stand alone as it is related to other texts), suggesting that there is the work of old texts to produce new texts. However, printed text (or the phenotext as referred to in semanalysis) is not a structured meaning. The meaning must be revealed. Phenotex, according to semanalysis, is only understood through genotext as it is its origin. Phenotex is a surface, which is a marked structure, whereas genotext is a significant productivity (foundation).

According to Kristeva, the development of a semiotic theory is closely related to the development of individual personalities. It is stated in all-textual order that each of semiotic and symbolic corresponds to phenotext and genotext. Genotext is the process (in meaning) while phenotext is the meaning that is in accordance with communicative language. Both are place arrangements in the search for a meaning. Phenotext and genotext cannot stand alone, according to Kristeva. Both of them are simultaneous as a sign (Sutrisno-Putranto, 2005: 225).

\section{Methods}

This study conducted to observe and examine the representation of meanings of a woman's body on the relief panels of the walls of Borobudur temple is a qualitative research. According to the researchers, the research activities aim to investigate a problem carefully and perfectly to result in the right solution. Qualitative research method uses a variety of meanings in different ways across disciplines.

Denzin-Lincoln, in their book The Hand Book of Qualitative Research, presents the definition by Nelson-TreichlerGrossberg (1992), stating that:

A qualitative research is a space across disciplines, which sometimes is counter-disciplines in nature. It covers the field of humanities, social sciences, and physical sciences. It may mean many things at the same time as it has a focus on research with a variety of paradigms. The researchers are sensitive to the values of the various approaches. 
They are firm with a naturalistic point of view and are also strong with interpretive understanding of human experience. At the same time, this type of research is known for its political characters, and is shaped by a variety of ethical and political positions. It embraces two tensions at the same time. On the one hand, it is directed towards critical, feminist, post-modern, interpretive and broad understandings. While on another, it is directed towards the conception of human experience and its post-positivist analysis, which has been narrowly defined (Denzin-Lincoln, 2009: 5).

The researchers use interpretive paradigm for the research and writing of this dissertation. According to them, the interpretive paradigm is a way to provide an interpretation of an object (or subject) by separating the realities that exist in human experience. According to Denzin-Lincoln, interpretiveism is shaped by ideas that emerged from the hermeneutical traditions and historical interpretations were the hallmark of human research. This research mentions the rejection of the naturalistic interpretation of social science, and states that the aims and methods of social science are identical to natural science. The purpose of social science is to understand meanings or know the meanings of social phenomena (Denzin-Lincoln, 2009: 148).

The approach used in this research on the representation of the meaning of a woman's body displayed on the relief panels of the Borobudur temple is the intertextual narrative research by Julia Kristeva. Denzin-Lincoln mentions that it is important for qualitative researchers to focus and question the various situations of women that are different from a certain period of time, and the various institutions and frames that affect the situation (Denzin-Lincoln, 2009: 198).

In the framework of narratives, current hegemony may be utilized as a tool in understanding female characters and the truth of their stories, and at the same time allows researchers to explore how to tell the stories (in the relief panels) in spite of limited context. This approach also allows researchers to identify existing narratives, or special or dominant narratives as a guide to limiting or freeing the narratives or stories to convey.

\section{Result and Discussion}

Julia Kristeva coined the term intertextuality as a poststructuralist concept, and as a universal phenomenon that explains communicative interconnection between text and other texts, as well as text and context. According to the current researchers, the emergence of various theories in intertextuality now provides a wider range of meanings, because a text cannot exist or stand alone as a whole without any other existing text.

According to Kristeva, a text is combined from various quotes and is an assimilation from the making of other quotes, whereas intertextuality exists to restore intersubjectivity. In her book The Bounded Text, Kristeva mentions the process of making text outside the existing discourse. Text is defined as a trans-linguistic apparatus (or intermediary) that communicatively distributes language sequences, aiming to inform directly on various anterior or synchronous speech types. Text and intertextuality in practice intersect or mutually neutralize each other in between texts.

What about the relief panels displaying the female body on the Borobudur Temple's walls? The relief panels displaying the female body at Borobudur Temple can be interpreted as a text of stories. In the relief panels of various temples, various characters or figures can be found in different body positions, including lying down, walking, running and so on. Lydia Kieven suggests that a person's posture on a relief panel depends on their social status. For example, low status figures are often illustrated running, fighting or any other posture that describes violence. While figures with high social status are illustrated in subtle gestures. Likewise, the positions of the other parts of the body of a character are based on their social status (Kieven, 2017: 65). In the relief panels, the illustration of the female body depicts more sexual, or at least sensual, behaviors. In a romantic atmosphere, a woman's body in the relief panels is generally depicted with untied hair, holding their heads in a lying position to the side, and touching their heads with one hand.

Borobudur's relief panels display many female figures that are worth the visitors' attention. The representation of a woman's body in these relief panels is quite interesting to be used as a research material or just for a discussion with other male relatives. Their roles are emblazoned on the relief panels, and they are very diverse, ranging from ordinary women, princesses to holy women. The context of the female body in the Borobudur's relief panels is also very closely related to the existing texts. Their roles as either an object of female beauty or an art object should be considered when looking at a woman's body on the relief panels, including the aesthetics and the body in addition to the meaning of the body itself (Sutrisno-Putranto, 2005: 319).

In examining a woman's body displayed on the relief panels of Borobudur's walls, the researchers conduct a textual study by looking at the physicality of the relief panels as a stand-alone text. The carvings of the female body on the relief panels of Borobudur temple is a text that can be read and analyzed textually using several concepts of understanding. In this study, semanalysis by Julia Kristeva is used with genotext and phenotext. Kristeva mentions her view of language as something statically bound that can be accepted by consciousness, and overrides material, heterogeneous and unconscious dimensions. Kristeva develops the semiotic theory from here, which was related to the development of individual personalities. 
Kristeva affirms that in a completely textual, semiotic and symbolic order, each of them is related to what is called genotext and phenotext. Genotext is not linguistic (language); it is rather a process, while phenotext is in accordance with communicative language (Sutrisno-Putranto, 2005: 224).

Genotext is the original text or meaning, while phenotext is the actual text or meaning understood in the current time. Genotext and phenotext are always present together. Furthermore, according to Julia, human daily activities are discourse formation activities and meanings. The process is called signifier and signified. Genotext comes from the Greek word genêtikos. "geno" represents something that is "specific for generations", in relation to "genesis" and "production". Genotext is in accordance with the process of producing a marking system (production marking). Genotext is not a structure; it represents the infinity of indicating. Genotext does not reveal the marking process; but offers all possible marking processes.

The texts contained in the display of the female body on the Borobudur's relief panels can be interpreted as genotext and phenotext. In the genotext meaning, or the original meaning, the sculpture of the female body basically portrays the posture of a woman's body in general, whether without jewelry or not. In the appearance, the female body carved in the relief panels depicts the beauty of women with body image and sexuality in general.

The definition of the word "beautiful" changes over time for a woman, when related to the meaning of genotext and phenotex. The meanings of the word vary. Women with fair skin may be considered beautiful, and dark-skinned women may still fall into the category too. Women with a slim body may be considered beautiful, and the same thing applies, too, to them with a large body. The meaning of an appearance of a beautiful female body often experiences a shift over time.

The female body, either in real life, artworks, or relief panels of temples, has more or less the same meanings. They may be true meanings (genotext), or that of existing or favored by many people (fenotext), in the context of semiotic analysis.

The appearance of the female body in the relief panels is a symbol that can be read as a text. In the genotext meaning (initial meaning), the women who appear without clothings, or naked, are considered appropriate. Some data obtained from various sources mention that this was normal in that era, especially in the period before the 10th century. Another factor that may affect the situation is the climate of the tropical Indonesia. Tropical regions are hot and humid, so clothes may become wet from sweating, and it will stay wet (moist) for a long time, and it may be health-challenging. These are the two factors that may have affected the way women dress before the 10th century, hence the bare-chested portrayal.

In genotext meaning (original meaning), bare-chested women in those days do not affect the views of people around them, especially men. Women are subjects who are not judged on their body shape; they are valued by mystical attraction. However, the relief panels may be representative to the appearance of women at that time. The shape of the body and face is the result of the relief sculptors' imagination at that time.

In phenotext meaning (the one existing today), the appearance of women who appear without clothes conveys negative meanings which may lead to pornography and legal actions. In the period before the 10th century, appearing barechsested or topless was common, but not today; it can lead to unlimited and uninvited male interest. Women will become a target to fight for, specifically their bodies. Additionally, in this era, women appearing in public without wearing anything can attract crimes to themselves.

Switching the discussion to body shapes, a large female body, with a specifically large abdomen, large hands and muscular legs (or fat) may have been attractive to the majority of men in the old times, because women with that type of body were considered to be more fertile and can bring many offspring. Whereas in the present time, having a large or fat body is a big issue for women, as many of them will be shunned by men, and will also be considered difficult to bear a child.

In terms of the natural meaning of a large or fat female body, differences in past and present interpretation are inevitable. In the old times, women with a fat body were considered easy to be friends with, or very sympathetic, and old-fashioned looking. As explained earlier, they were also sought after by men because they were considered to be more fertile and will bring many offspring. It is clearly in contrast with the current interpretation of fat women, as they are thought to have a high temper, to become angry more easily, and to have difficulties in getting along and socializing.

In general, the shape of the human body can affect people's image when it comes to social life. In addition to affecting the physical attractiveness of the body, it can also affect whether or not someone is easily accepted in social life. Many women's social lives are affected by their uncommon body shape, even though they do not exactly want it to. 
For example, obese women who are generally friendly may change their attitude towards people as they demean or even insult their bodies.

Berger-Luckmann (1990: 28) states that human appearance in everyday life is interpreted by one another as a subjective meaning, in the sense that when they see the appearance of others, especially women, their actions are controlled by their thoughts. Based on this statement, it is understandable that women who appear have a beautiful body, either naturally or with some efforts done, will become the object of attention, and those who see it will interpret it according to their respective imagination.

\section{Conclusion}

A woman's body is prone to exploitation as it is proven to have economic values that can be developed for a variety of interests and specific purposes. In the relief panels of Borobudur temple, the female body is almost all constructed to become a text, conveying stories that can be easily recognized and understood.

The body can be considered a text, as can the relief panels displaying the female body the walls of temples, such as Borobudur. As a text, everything in it that can be read or interpreted. A text can become a language, or linguistic in nature. It is a semiotic practice that is realized across all languages without diminishing the intention of the original language. In this perspective, a text can be defined as a translinguistic tool that redistributes grammar by connecting communicative conversations, which purpose is to channel information directly, through various kinds of anterior or synchronic expressions. Therefore, a text can be explained as human relationship with language. In interpretative meaning of a text, discursive understanding or the ability to interpret must be mastered by researchers or people who want to know the meaning of a text through symbols.

Intertextuality means that in writing or reading or understanding a text, one is always motivated by other texts. The same concept applies to the meaning of the text too, which means it is always related to the context and cannot be limited to certain contexts only. Julia Kristeva mentions that each text contains quotations and is a transformation of other texts. In interpreting or understanding new texts, background knowledge about the text that preceded it is needed. A text is a series or construction of various quotations or paraphrases from other texts, either consciously or not. The intertextuality approach can be used to understand the rules, epistemology and time of the situations contained in a text.

\section{References}

Arsam, Politik Tubuh Perempuan Jawa, Deepublish, Yogyakarta, 2016

Baudrillard, Jean, Seduction, New World Perspectives CultureTexts Series, Montreal, 1990

Berger, Peter L. - Luckmaan, Thomas, Tafsir Sosial Atas Kenyataan, LP3ES, Jakarta, 1990

Denzin, Norman K. - Lincoln, Yvonna S., Hand Book of Qualitative Research, Pustaka

Pelajar, Yogyakarta, 2009

Kieven, Lidya, Menelusuri Panji di Candi-candi, Kepustakaan Populer Gramedia, Jakarta, 2017

Kristeva, Julia, Desire In Language : A Semiotic Approach to Literature and Art, Columbia University Press, New York, 1980

Kristeva. Julia, Revolution in Poetic Language, Columbia University Press, New York, 1984

Kristeva, Julia, Strangers to Ourselves, Columbia University Press, New York, 1991

Kristeva, Julia, The Black Sun, Columbia University Press, New York

Kristeva, Julia, The Power of Horror : An Essay on Abjection, Columbia University Press, New York, 1982

Piliang, Yasraf Amir, Postrealitas : Realitas Kebudayaan dalam Era Postmetafisika, Jalasutra, Yogyakarta, 2013

Raditya, Ardhie, Sosiologi Tubuh - Membentang Teori di Ranah Aplikasi, Kaukaba Dipantara, Yogyakarta, 2014

Sihabudin, Ahmad, Komunikasi Antar Budaya - Satu Perspektif Multi Dimensi, Bumi Aksara, Jakarta, 2013

Sutrisno, Mudji - Putranto, Hendar, Teori-Teori Kebudayaan, Kanisius, Yogyakarta, 2005

Sadehi, Camelia Talebian, Beloved and Julia Kristeva's The Semiotic and The Symbolic,

Department of Foreign Languages, University of Amin, Isfahan, Iran, Journal Theory and

Practice in Languages Studies, Volume2 No. 7, 2012

Zengin, Mevlude, An Introduction to Intertextuality as a Literary Theory : Definitions, Axioms,

Band The Originators, Journal Pamukkale Universitesi, Social Bilimler Enstitusu Dergisi, Sayi 25/1, 2016 